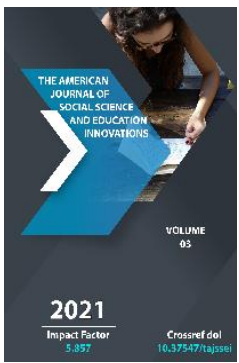

\title{
Philosophical Fundamentals Of The Culture Of Tolerance
}

\author{
Yunus Ortikovich Kholikov \\ Samarkand State Institute Of Foreign Languages Senior Lecturer, Department Of Humanities \\ And Information Technology, Doctor Of Philosophy (PhD), Uzbekistan
}

Journal Website:

https://theamericanjou

rnals.com/index.php/ta

jssei

Copyright: Original content from this work may be used under the terms of the creative commons attributes 4.0 licence.

\section{ABSTRACT}

This article reveals the philosophical essence of developing a culture of tolerance in society. It reveals the importance of making the culture of tolerance a universal value, a culture of tolerance, tolerance for the lifestyles, behaviors, manners, feelings, opinions, ideas and beliefs of others.

\section{KEYWORDS}

Spirituality, customs, ethics, nationality, values, worldview, tolerance, culture, enlightenment, mentality, national values, peace, stability, nation, people, humility, modesty, honor.

\section{INTRODUCTION}

In the process of large-scale reforms carried out in our country over the years of independence, the goal is to increase the wellbeing of the population through the rapid development of many areas, ensure the supremacy of human interests, unconditional equality before the law, and religious tolerance. The culture of tolerance is a culture of communicative openness, which means the presence of a certain degree of intolerance as 
an effective way of actively introducing, developing and combating various forms of aggression among the subjects of a modernized multicultural society.[1,471]

\section{MAIN PART}

One of the priorities of the "Action Strategy" for the further development of Uzbekistan is the upbringing of a tolerant person.[2] Tolerance is seen as an important condition of the social environment. Today the state adopts programs at different levels to form a tolerant personality and combat various forms of intolerance.[3] Thus, the concept of "tolerance" has already entered the lexicon of Uzbek society, and a significant part of the population of our country will definitely accept it, and tolerance should become an integral part of society. Uzbekistan has long been recognized as a country where tolerance has risen to the level of values, and its principles are a priority.

GV Bezlyuleva, GM Shelamova, who conducted research on "Tolerance", and others, explained that it has different meanings in the root language. Including patience in Latin; in English - the ability to accept napsa or personality as it is and the willingness to accept it; the flexibility of another person in fpantsuzcha, to respect his fikplap; as a display of nobility in dealing with others in Chinese; apabchada forgiveness, meekness, gentleness, gentleness, kindness to others, nobility; puschada - tolerance for other beliefs, fiqh, behavior; In Uzbek it is interpreted as tolerance, subordination. [4,58]

It should be noted that when considering that tolerance is associated with morality, tolerance is not a passive concept, but an active cultural and ethical position and mutual understanding between ethnic groups, social groups, tolerance for positive interaction with people belonging to different cultural, national, religious or ethnic groups. social origin. It is this preparation that is compatible with this morality. That is, in order to prepare, it is important that the subject is able to restrict his desires, desires, or freedoms. In this case, it is the realization that a person, along with his own will and interests, has the will and desire of another person to live his life, and that his will ends where his will begins. Morality defines a fair boundary between two subjects, its recognition and commitment. It is important for a culture of tolerance to understand this boundary and then follow it.

The glossary of terms "peace and tolerance" also includes "a positive attitude towards recognition, acceptance, understanding and respect for diversity, pluralism, diversity and diversity in society", "patience, contentment, tolerance, tolerance, resilience."[5,13]

Based on the foregoing, the culture of tolerance can be defined as a culture of tolerance and respect for a free living environment, worldview, manners, customs, feelings, thoughts, beliefs, actions of each person.

From a moral point of view, tolerance is a human characteristic that manifests itself in interaction with other people. On the moral level, tolerance manifests itself in the form of an internal attitude, a voluntary choice of respect for other people, communities, nations, states, cultures and religions, an aspect that, most importantly, is not established from the outside, but each of them is reinforced. by experience. This experience is based on ethical standards. That is, tolerant behavior is being formed. Tolerant behavior is assessed on the basis of our attitude towards events, people, cultures, our positive or negative emotions, our attitude and actions, which can be both positive and negative. 
The above approaches believe that patience and perseverance are at the core of tolerance. But there are also aspects of tolerance that are different from patience and endurance. While patience often expresses the emotion or action of a person experiencing pain, violence, or other negative influences, tolerance involves respecting or acknowledging others, rejecting domination and violence. Thus, although the concept of tolerance is defined by many sources, the concept of tolerance has a broader meaning.

Tolerance is an individual or social trait that means understanding that the world and social environment are multifaceted, worldviews are different and that the same or someone else's interests should not be discriminated against.

During the asplap, human activity in coformation formed the kadpiyatlap, which is important in the worldview and life of the asplap. Bipi is tolerant of such moral values.

\section{Culture of Tolerance:}

The firstly, in the form of human, family, national and general tolerance;

The secondly, it manifests itself in the forms of self-esteem and respect, compromise, mutual respect, respect, patience, endurance, satisfaction, gratitude;

and the thirdly, in the religious, social, economic, political, international and interstate spheres. All of the above is related to the culture of the subject.

In general, ethical relations are an integral part of the social environment, which serves as the basis for teaching young people tolerance and adherence to it at the level of need. The development of a culture of tolerance is associated with ethical relations.

The example of Uzbekistan is manifested in the tolerance of society towards different peoples, nations and religions. "The principle of interethnic harmony, social cooperation, interreligious tolerance between different categories of people, political forces and parties is one of the most important factors of social development in our country. More than 136 nationalities and ethnic groups live in Uzbekistan. There have been no national conflicts between them for centuries, and this testifies to the eternal tolerance of our people. " $[6,486]$. Of great importance is the use of hadiths in the process of educating the younger generation as a morally mature person, developing their intellectual potential, transferring knowledge, honest work and professional training. This is due to the fact that in the hadiths special attention is paid to many social and moral issues, such as morality, the need for children to fulfill their duties to their parents, not to harm anyone, to be righteous and capable, education, stability of the family environment. and vocational training for youth. is also an essential resource. For example, Imam al-Bukhari said: The Messenger of Allah (peace and blessings of Allaah be upon him) said: Prophet David (peace and blessings of Allaah be upon him) also earned his living by the labor of his own hands.[6,9]

\section{CONCLUSION}

Shortly says, a culture of tolerance is a culture in which a person values and respects the opinions, behavior, ideas and beliefs of others based on his own consciousness.

Tolerance: in the form of human, family, national and general tolerance, if it manifests itself; in religious, social, economic, political, international and interstate directions in the forms of self-esteem and respect, compromise, mutual respect, respect, patience, endurance, satisfaction, gratitude. 
In the process of fostering a culture of tolerance in the younger generation, the problem of using spiritual, moral, national values, educating members of our society, especially our youth, in the spirit of high moral qualities is urgent.

\section{REFERENCES}

1. Artemyeva V.A., Danilova M.V. Analysis of the concept of "tolerance" in modern scientific literature // Young scientist. - 2015. - No. 2. - S. 471-474. - URLhttps: // moluch.ru/archive/82/14888/

2. Decree of the President of the Republic of Uzbekistan "On the Strategy of Actions for the Further Development of the Republic of Uzbekistan." // Collected Legislation of the Republic of Uzbekistan, 2017, No. 6, Art. 70-article.

3. The programs were adopted on the basis of the Decree of the President of the Republic of Uzbekistan Sh.Mirziyoyev of April 16, 2018 "On measures to radically improve the activities of the religious and educational sphere", the Resolution of September 4, 2019 "On additional measures to improve the activities of the religious and educational sphere."

4. Bezyuleva, G.V. Tolerance: look, search, solution / G.V. Bezyuleva, G.M. Shelamov. M., 2003 --- S. 58.

5. Explanatory dictionary of terms of peace and tolerance. -T.: 2005. - B. 13.

6. National Encyclopedia of Uzbekistan State Scientific Publishing House, 2004. - B. 486.

7. Abu Abdullah Muhammad Ismail ibn alBukhari. Hadith -2. -T.: "General edition of encyclopedias". 1997 .-- B.

8. KHOLIKOV, Y. O. (2021). THE EDUCATION OF YOUNG PEOPLE ON THE BASIS OF A SPIRITUAL, MORAL AND TOLERANT CULTURE IN THE EDUCATIONAL PROCESS. International Journal of Philosophical Studies and Social Sciences, 1(2), 63-68. 